\title{
Talent Retention through Employee Engagement, Human Resource, Knowledge and Change Management: A Conceptual Framework
}

\author{
Dorothea Kossyva*, Georgios Theriou, Vassilis Aggelidis and Lazaros Sarigiannidis \\ Management Science and Technology Department, School of Economics and Business, International \\ Hellenic University (IHU), Kavala, Greece
}

\section{ARTICLE INFO}

\section{Keywords:}

Human Resource Management

Knowledge Management

Change Management

Employee Engagement

Turnover Intention

\begin{abstract}
This study examines talent retention in the Information and Communication Technology (ICT) sector by focusing on the relationships between human resource management (HRM), knowledge management (KM), change management (CM) and employee engagement. In this respect, a conceptual framework is proposed to understand the relationships between these constructs. The proposed framework highlights the importance of implementing specific talent retention practices in knowledge-intensive sectors like ICT, in order for employees to be engaged both with their work and their organization.
\end{abstract}

\section{Introduction}

In today's constantly changing and demanding business environment, it is crucial for firms to continuously attract and retain talented employees who possess valuable skills, knowledge and capabilities (Ambrosius, 2018). Many researchers (e.g., Khilji et al. 2015; Tarique \& Schuler, 2018) argue that talent management contributes significantly to financial performance and business survival. In this context, firms spend significant time and resources to design and implement talent management practices in order to attract and retain talented workers. Several researchers (e.g. McNulty, 2018) support that the overall process involves a distinct strategic dimension which provides firms with competitive advantages. According to McDonnell (2011), the "war for talent" is extremely important, as human capital is considered to be one of the key factors for firms to achieve long-term organizational success (Pandita \& Ray, 2018).

The definitions for the term "talent" varies. For example, Michaels et al. (2001, p. 12), proposes that talent is "the sum of a person's abilities-his or her intrinsic gifts, skills, knowledge, experience, intelligence, judgment, attitude, character and drive. It also includes his or her ability to learn and grow". In addition, Silzer \& Dowell (2010, p. 14) define talent as "An individual's skills and abilities (talents) and what the person is capable of doing or contributing to the organization". In an in-depth literature review regarding the meaning of talent, Gallardo-Gallardo et al. (2013) categorized two broad approaches: (1) objective approach, which considers talent as distinctive characteristics of people within organizations, and further distinguishes talent as natural ability, talent as mastery, talent as commitment and talent as fit, and (2) subjective approach, which includes the inclusive approach, i.e.

\footnotetext{
* Corresponding author E-mail address: dorakossyva@gmail.com

Kossyva, D., Theriou, G., Aggelidis, V., \& Sarigiannidis, L. (2021). Talent Retention through Employee Engagement, Human Resource, Knowledge and Change Management: A Conceptual Framework. International Journal of Applied Research in Management and Economics, 4(2), 35-45. https://doi.org/10.33422/ijarme.v4i2.631
}

(C) The Author(s). 2021 Open Access. This article is distributed under the terms of the Creative Commons Attribution 4.0 International License, which permits unrestricted use, distribution, and redistribution in any medium, provided that the original author(s) and source are credited. 
organizations consider all employees as talents, and the exclusive approach, i.e. organizations consider a distinct group of employees as talents who perform exceptionally or have the potential to became high performers. As human resources are limited, organizations have to be able to retain their high performers in order to achieve the desired organizational outcomes (Hsu, 2008).

Although previous studies (e.g., Bhatnagar, 2007; Kundu \& Lata, 2017) investigated the impact of employee engagement on talent retention, further research is needed to examine talent retention in ICT sector. In fact, there is limited research regarding talent retention in ICT sector, in which the "war for talent" is relentless, as organizations compete to attract and retain the most capable employees.

This study proposes a conceptual framework for examining the relationships between human resource management (HRM), knowledge management (KM), change management (CM) and employee engagement, and the relationship between employee engagement and turnover intention. The conceptual framework will be implemented to the Information and Communication Technology (ICT) sector, which is a constantly changing knowledgeintensive sector. Therefore, the need for properly managing change and knowledge as well as human capital is imperative. The present study adopts the exclusive approach and considers "high performance talents" as high-skilled knowledge workers who possess valuable skills and capabilities.

The article is divided into three sections. Firstly, the proposed conceptual framework is described, secondly, a theoretical support of the proposed framework is provided based on the extant literature of the constructs under examination and finally, conclusions are discussed.

\section{The Proposed Conceptual Framework}

Today's business environment requires organizations to be more resilient to change and constantly create new knowledge if they want to survive. In the ICT sector, which is a knowledge-intensive sector, organizations are dealing with rapid technological change and intense competition globally (Holm \& Østergaard, 2015). In this respect, organizations in the ICT sector are called to attract and retain talented employees (Ambrosius, 2018). Due to the sector characteristics, the authors consider talented employees as knowledge workers, i.e., employees who work in knowledge-intensive sectors and possess valuable skills and capabilities (Drucker, 1989), who they are actively involved in the knowledge management process.

Furthermore, in order for an organization to create a sustainable competitive advantage, lies in its ability to manage both human and intellectual capital (Hsu, 2008; Alkhalil et al., 2014). The first one stems from the resource-based view (RBV) of the firm which describes an organization as a set of tangible and intangible resources and capabilities that distinguish it from competitors. The basic assumption of this theory is that sustained competitive advantage comes from valuable, rare combinations of resources available to a firm, which are difficult to be imitated, acquired and reproduced by its competitors (Barney, 1991; Grant, 1991). The latter focuses on the knowledge-based view (KBV) of the firm, which is based on RVB. Knowledge-based view considers knowledge as a strategic resource for an organization which if managed properly, can lead to the development of sustainable competitive advantages (Kogut \& Zander, 1992; Wiklund \& Shepherd, 2003).

The following conceptual framework initially examines the relationships between three constructs, i.e. human resource management, knowledge management and change management, related to the ICT sector, which is a knowledge-intensive sector, characterized by constant change, aiming at recruiting and retaining knowledge workers. Furthermore, the three mentioned constructs are investigated as antecedents of employee engagement in order 
to identify whether human resource, knowledge and change practices of organizations can lead to highly engaged knowledge workers who are attached to both their job and their organization. Finally, the relationship between employee engagement and turnover intention is examined and it is supported that highly engaged knowledge workers are not intent to leave their work voluntarily.

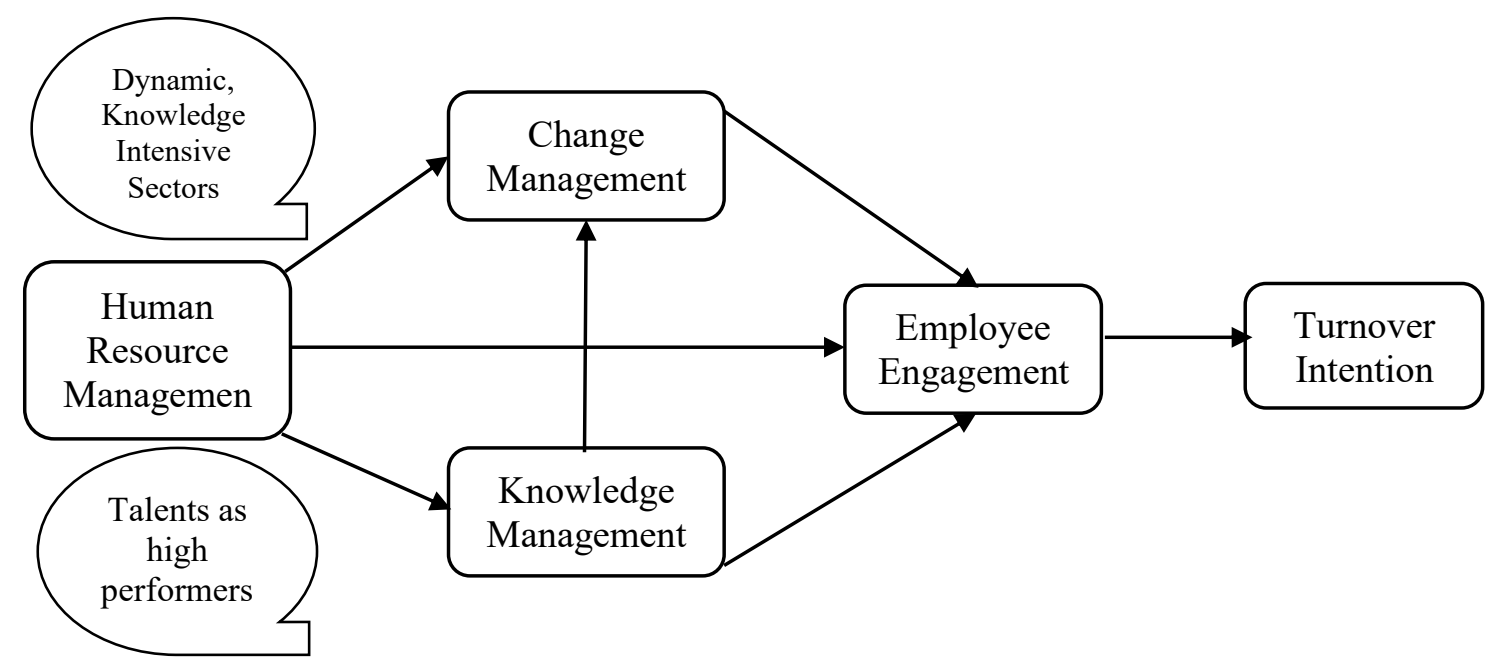

Figure 1. Proposed conceptual framework

\section{Theoretical support of the proposed framework}

The following subsections provide theoretical support for the above proposed conceptual framework.

\subsection{Human Resource Management and Change management}

Human resource management (HRM) is responsible for the recruitment and selection of employees as well as to support them through the whole process of employment (De Boeck et al., 2018). In addition, since organizations are constantly forced to adapt to changing conditions, HRM's challenge is to be able to develop an organizational culture which embraces change so that employees will be more receptive to change and better deal with it (Carmeli \& Spreitzer, 2009; Tummers et al., 2015). Organizational change involves HR professional's efforts, who act as agents of change, to clearly communicate the change process to their employees enabling them to be more adaptive towards change (Petrou et al., 2016). According to Tummers et al. (2015), HRM practices, such as job autonomy, participation in decision making and quality teamwork, can improve employees' abilities to cope with organizational change. Therefore, successful organizational change stems from employees' active behaviors, such as higher levels of proactivity and vitality.

\subsection{Human Resource Management and Knowledge management}

It is widely accepted that knowledge is one of the most significant resources of organizations (e.g., Nonaka \& Takeuchi, 1995). Organizations are called to manage their knowledge through their employees in order to gain competitive advantages. Knowledge management $(\mathrm{KM})$ is generally defined as an organizational process of knowledge creation, knowledge acquisition, knowledge capturing, knowledge sharing and knowledge application to increase organizational performance and learning capability (Grant, 1996; Spender, 1996; Scarbrough et al., 1999; Alavi \& Leidner, 2001). KM process is dependent on knowledge workers' skills, capabilities, education and participation as well as on HRM process, which is responsible for recruiting, selecting, developing, educating, compensating and rewarding them (Carter \& 
Scarbrough, 2001; Oltra, 2005). According to Oltra (2005), people and knowledge are two interrelated concepts. Davenport and Prusak (2000, p. 43) argued that knowledge workers not only should be urged to create and share knowledge but also they have to be rewarded for their efforts (Esterhuizen et al., 2012).

In this respect, human resources have a vital role in KM process as one of their main responsibility is to manage knowledge workers whose most significant asset is knowledge (Andreeva \& Kianto, 2012). This comes to an agreement with many studies which have explored the relationship between HRM and KM. For instance, various studies examined the impact of HRM practices on intra-organizational knowledge sharing (e.g., Liu \& Liu, 2011; Chen et al., 2011), while other studies focused on a broader perspective exploring the relationships between different HRM practices with the whole KM process (Jimenez-Jimenez \& Sanz-Valle, 2013).

More specifically, Liu \& Liu (2011) investigated the relationship between HR practices and individual knowledge sharing of R\&D professionals in high-tech industries and they found that HR practices, like incentive compensation plans face-to-face communication and performance appraisal systems, facilitate knowledge-sharing behavior through the enhancement of employees' perceived self-efficacy and willingness to knowledge sharing. In addition, drawing on dynamic capability view (DCV), Turulja \& Bajgoric (2018) found that HRM capability promotes KM capability and their interaction enhances business success. Furthermore, the findings of Jimenez-Jimenez \& Sanz-Valle's (2013) empirical research showed that there is a positive relationship between knowledge-oriented HR practices and knowledge management processes, such as knowledge acquisition, distribution, interpretation and storing.

\subsection{Knowledge Management and Change Management}

People within an organization, i.e. knowledge workers, create explicit and tacit knowledge whether individually or collectively through knowledge sharing (Nonaka, 1994). Knowledge management strategies are considered to play a significant role for successful organizational change initiatives as they can contribute to communicate information through the change process (Hansen et al., 1999; Imran et al., 2016). Additionally, in every phase of organizational change process, different types of knowledge are required for the achievement of change implementation (Bierly et al., 2000). Imran et al. (2016) found that KM strategies, such as personalization which is based on tacit knowledge and codification which is based on explicit knowledge, indirectly influence successful organizational change via organizational learning and change readiness.

\subsection{Employee Engagement and Its Relationship with Human Resource Management, Change Management and Knowledge Management}

Employee engagement signifies an organizational perspective for managing the workforce which includes the whole working experience of employees' interaction and involvement with their work, team and organization (Truss, 2014; Shuck et al., 2017). In addition, it involves three subdimensions: (1) cognitive engagement, which implies employees' fully attention and concentration on their whole working experience, (2) emotional engagement, which denotes employees' eagerness to emotionally involved with their workplace and (3) behavioral engagement which constitutes employees' psychological willingness to work more than the expected (Shuck et al., 2017).

According to Kettler (2008), organizations are looking for ways to enhance employee engagement whether through the creation of employee development programs or employee surveys to determine their long-term plans. Saks (2006) argued that there are antecedents of 
engagement which can promote the generation of engaged employees. The present study aims to explore HRM, CM and KM as antecedents of employee engagement in the ICT sector which is considered a dynamic knowledge-intensive sector. Therefore, in this constantly changing industry, HR managers are called to deal with attracting, recruiting, developing and retaining talented employees whose most valuable resource is knowledge.

Although this study proposes a direct relationship between HRM and employee engagement, we consider that the indirect relationship between HRM and employee engagement through $\mathrm{CM}$ and $\mathrm{KM}$ might be more significant due to the specific characteristics of the ICT sector.

\subsection{Human Resource Management and Employee Engagement}

Several studies (e.g., Juhdi et al., 2013; Vuong \& Sid, 2020), which examined the relationship between HRM and employee engagement, have concluded that HRM has a pivotal role in enhancing the engagement of employees. More specifically, Alfes et al. (2013) argued that "employees who have a positive perception of the HRM practices in their organization are more engaged with their jobs". HRM practices constitute a part of HRM activities which are concerned with employees' management and development as well as the relationship among them (Vuong \& Sid, 2020). Empirical studies have found that different HR practices, such as career management, person-job fit, pay satisfaction, performance appraisal, job control, career advancement, job security and performance feedback, are positively related to employee engagement (Juhdi et al., 2013; Aktar \& Pangil, 2017). At the same time, employee engagement plays a critical role as a mediator between HR systems and both individual and organizational outcomes, such as employees' innovative behavior, task performance, turnover intention and organizational citizenship behavior (Alfes et al., 2013; Shantz et al., 2013).

\subsection{Change Management and Employee Engagement}

Change management (CM) has rarely been investigated as an antecedent of employee engagement (e.g., Sonenshein \& Dholakia, 2012). In a fast-moving changing business environment, leaders are called to prepare their employees to get ready for change by urging them to be more receptive to change and adapt more easily to their working environment (Armenakis \& Harris, 2002; Matthysen \& Harris, 2018). According to Marks (2007), organizations which facilitate change practices such as open communication, knowledge sharing and participation, urge their employees to be more engaged with their job. Otherwise, when organizations fail to manage change, this might have negative effects on organizational outcomes as well as on employees' well-being. As a result, employees will become disengaged both with their work and their organization (Marks, 2007; Matthysen \& Harris, 2018). Therefore, organizations which embrace change practices and communicate them to their employees enable them to be involved in the organizational change process (Parent et al., 2012).

\subsection{Knowledge Management and Employee Engagement}

Knowledge management (KM) has not been sufficiently explored as an antecedent of employee engagement. In fact, few studies examined the impact of knowledge management processes on employee job satisfaction which is partly related to employee engagement (e.g., Kianto et al., 2016; Singh \& Sharma, 2011).

Knowledge workers constitute an integral part of their organizations as they are actively involved in the knowledge management process. According to knowledge-based view (KBV) of the firm, knowledge is a valuable resource within an organization which contributes to the generation of sustainable competitive advantages (Kogut \& Zander, 1992; Wiklund \& Shepherd, 2003). Knowledge workers who possess and share knowledge resources could be 
the enablers of innovation outcomes and business success. In this respect, they might be more attached to their organizations as they feel valuable parts in the knowledge creation process. Kianto et al. (2016) argue that the implementation of KM processes within an organization can create positive attitudes of employees about their work. Therefore, the authors suggest that knowledge workers will be more engaged with their jobs and their organizations when they experience KM processes in their workplace.

\subsection{Employee Engagement and Turnover Intention}

As stated previously, employee engagement describes the whole experience of a person's cognitive, emotional and behavioral involvement with his or her work, team, job and organization (Shuck et al., 2017). Highly engaged employees are more enthusiastic and attached to their work and they have positive feelings towards their organization (Shantz et al., 2013). On the contrary, employees who are not highly engaged with their work, they would be more likely to leave their organization (Shantz et al., 2014).

According to various studies (e.g., Schaufeli \& Bakker, 2004; Albrecht \& Marty, 2020), employee engagement has a negative effect on turnover intention both directly and indirectly. Employee turnover intention is considered as an attitudinal outcome where employees have the intention to leave their work voluntarily (Griffeth et al., 2000; Falkenburg \& Sachyns 2007). In addition, as turnover intention is associated with actual turnover (Van Schalkwyk et al., 2010), organizational performance is negatively affected when high skilled and talented employees quit their jobs (Bentein et al., 2005). Therefore, high levels of employee engagement within an organization could lead to the retention of valuable employees.

\section{Discussion and Conclusions}

The present study proposes a conceptual framework with various relationships which is suggested to be implemented to the ICT sector. More specifically, the study attempts to theoretically support the relationship between HRM, KM and CM as well as their relationship with employee engagement. In addition, the relationship between employee engagement and turnover intention is examined, focusing on skills, capabilities, attitudes and perceptions of knowledge workers. This kind of high-skilled employees in the ICT sector are usually characterized as talents within the exclusive approach of talent managers which views talents as high performers (Gallardo-Gallardo et al., 2013).

The extant literature showed that HRM, KM and CM are related to each other. Regarding the relationships between the three constructs and employee engagement, the review showed that HRM has a significant role in advancing the engagement of employees (e.g., Vuong \& Sid, 2020). Similarly, through KM processes, organizations are able to create positive employees' attitudes so that they will be more engaged with their jobs and their organizations (Kianto et al., 2016). Although the empirical investigation of change management as an antecedent of employee engagement is rare, Marks (2007) argued that when change practices such as open communication, knowledge sharing and participation are facilitated within organizations, the employees tend to be more engaged with their work. Additionally, when it comes to the relationship between employee engagement and turnover intention, various studies (e.g., Schaufeli \& Bakker, 2004; Albrecht \& Marty, 2020) showed that there is a negative relationship between them as employees who are highly engaged both with their work and their organization, they are not intend to leave them voluntarily.

To sum up, this study aims to:

- Describe the constructs presented in the conceptual model based on the existing literature.

- Present the various relationships between the constructs under investigation.

- Discuss the value of the proposed conceptual model in the ICT industry, due to its specific characteristics mentioned above. 
Finally, the empirical examination of the proposed conceptual framework is suggested, in any knowledge-intensive sector (e.g., knowledge intensive services) which is characterized by continuous change and employ high-skilled workers who possess valuable skills and capabilities.

\section{Acknowledgment}

This research is carried out/funded in the context of the project "Talent retention in the era of change and knowledge: enhancing employee engagement" (MIS 5048310) under the call RESEARCH SUPPORT WITH EMPHASIS ON YOUNG RESEARCHERS PHASE B. The project is co-financed by Greece and the European Union (European Social Fund-ESF) by the Operational Programme "Human Resources Development, Education and Lifelong Learning 2014-2020“.

\section{References}

Aktar, A., \& Pangil, F. (2017). The Relationship between Employee Engagement, HRM practices and Perceived Organizational Support: Evidence from Banking Employees. International Journal of Human Resource Studies, 7(3), ISSN 2162-3058. https://doi.org/10.5296/ijhrs.v7i3.11353

Alavi, M., \& Leidner, D.E. (2001). Review: knowledge management and knowledge management systems: conceptual foundations and research issues. MIS Quarterly, 5(1), 107-136. https://doi.org/10.2307/3250961

Albrecht, S.L., \& Marty, A. (2020). Personality, self-efficacy and job resources and their associations with employee engagement, affective commitment and turnover intentions. The International Journal of Human Resource Management, 31(5), 657-681. https://doi.org/10.1080/09585192.2017.1362660

Alfes, K., Shantz, A. D., Truss, C., \& Soane, E. C. (2013). The link between perceived human resource management practices, engagement and employee behaviour: a moderated mediation model. The International Journal of Human Resource Management, 24(2), 330351. https://doi.org/10.1080/09585192.2012.679950

Alkhalil, S.S., Dahiyat, S.E., \& Aldalahmeh, A.M. (2014). Intellectual capital development and its effect on technical innovation in banks operating in Jordan. Journal of Management Research, 6(1), 211-238. DOI:10.5296/JMR.V6I1.4629

Ambrosius, J. (2018). Strategic talent management in emerging markets and its impact on employee retention: Evidence from Brazilian MNCs. Thunderbird International Business Review, 60(1), 53-68. https://doi.org/10.1002/tie.21799

Andreeva, T., \& Kianto, A. (2012). Does knowledge management really matter? Linking knowledge management practices, competitiveness and economic performance. Journal of Knowledge Management, 16(4), 617-636. https://doi.org/10.1108/13673271211246185

Armenakis, A.A., \& Harris, S.G. (2002). Crafting a change message to create transformational readiness. Journal of Organizational Change Management, 15, 169-183. https://doi.org/10.1108/09534810210423080

Barney, J.B. (1991). Firm resources and sustained competitive advantage. Journal of Management, 17(1), 99-120. https://doi.org/10.1177/014920639101700108

Bentein, K., Vandenberghe, C., Vandenberg, R., \& Stinglhamber, F. (2005). The Role of Change in the Relationship Between Commitment and Turnover: A Latent Growth 
Modeling Approach. Journal of Applied Psychology, 90(3), 468-482. https://doi.org/ 10.1037/0021-9010.90.3.468

Bhatnagar, J. (2007). Talent management strategy of employee engagement in Indian ITES employees: key to retention. Employee Relations, 29 (6), 640-663. https://doi.org/ $10.1108 / 01425450710826122$

Bierly, P.E. III, Kessler, E.H., \& Christensen, E.W. (2000). Organizational learning, knowledge and wisdom. Journal of Organizational Change Management, 13(6), 595-618.

https://doi.org/10.1177/1350507605049906

Carter, C., \& Scarbrough, H. (2001). Towards a second generation of KM? The people management challenge. Education \& Training, 43(4/5), 215-224. https://doi.org/10.1108 /EUM0000000005483

Carmeli, A., \& Spreitzer, G.M. (2009). Trust, connectivity and thriving: implications for innovative behaviors at work. The Journal of Creative Behavior, 43(3), 169-191. https://doi.org/10.1002/j.2162-6057.2009.tb01313.x

Chen, W.-Y., Hsu, B.-F., Wang, M.-L., \& Lin, Y.-Y. (2011). Fostering knowledge sharing through human resource management in R\&D teams. International Journal of Technology Management, 53, 309-330. https://doi.org/10.1504/IJTM.2011.038596

De Boeck, G., Meyers, M., \& Dries, N. (2018). Employee reactions to talent management: Assumptions versus evidence. Journal of Organizational Behavior, 39(2), 199-213. https://doi.org/10.1002/job.2254.

Esterhuizen, D., Schutte, C.S.L., \& du Toit, A.S.A. (2012). Knowledge creation processes as critical enablers for innovation. International Journal of Information Management, 32, 354-364. https://doi.org/10.1016/j.ijinfomgt.2011.11.013

Falkenburg, K., \& Schyns, B. (2007). Work Satisfaction, Organizational Commitment and Withdrawal Behaviours. Management Research News, 30(10), 708-723. https://doi.org/ $10.1108 / 01409170710823430$

Gallardo-Gallardo, E., Dries, N., \& González-Cruz, T. (2013). What is the meaning of 'talent' in the world of work? Human Resource Management Review, 23(4), 290-300. https://doi.org/10.1016/j.hrmr.2013.05.002

Grant, R.M. (1991). The resource-based theory of competitive advantage: implications for strategy formulation. California Management Review, 33(3), 114-135. https://doi.org/ $10.2307 / 41166664$

Grant, R.M. (1996). Toward a knowledge based theory of the firm. Strategic Management Journal, 17 (S2), 109-122. https://doi.org/10.1002/smj.4250171110

Griffeth, R.W., Hom, P.W., \& Gaertner, S. (2000). A Meta-Analysis of Antecedents and Correlates of Employee Turnover: Update, Moderator Tests, and Research Implications for the Next Millennium. Journal of Management, 26(3), 463-488. https://doi.org/ 10.1016/S0149-2063(00)00043-X

Hansen, M.T., Nohria, N., \& Tierney, T. (1999). What's your strategy for managing knowledge? Harvard Business Review, 77(2), 106 -116.

Holm, J.R., \& Østergaard, C.R. (2015). Regional Employment Growth, Shocks and Regional Industrial Resilience: A Quantitative Analysis of the Danish ICT Sector. Regional Studies, 49(1), 95-112. https://doi.org/10.1080/00343404.2013.787159 
Hsu, I. C. (2008). Knowledge sharing practices as a facilitating factor for improving organizational performance through human capital: A preliminary test. Expert Systems with Applications, 35, 1316-1326. https://doi.org/10.1016/j.eswa.2007.08.012

Iles, P., Chuai, X., \& Preece, D. (2010). Talent management and HRM in multinational companies in Beijing: Definitions, differences and drivers. Journal of World Business, 45(2), 179-189. https://doi.org/10.1016/j.jwb.2009.09.014

Imran, M.K., Rehman, C.A., Aslam, U., \& Bilal, A.R. (2016). What's Organization Knowledge Management Strategy for Successful Change Implementation? Journal of Organizational Change Management, 29, 1097-1117. https://doi.org/10.1108/JOCM-072015-0130

Jimenez-Jimenez, D., \& Sanz-Valle, R. (2013). Studying the effect of HRM practices on the knowledge management process. Personnel Review, 42(10), 28-49. https://doi.org/ $10.1108 / 00483481311285219$

Juhdi, N., Pawan, F., \& Hansaram, R. M. K. (2013). HR practices and turnover intention: the mediating roles of organizational commitment and organizational engagement in a selected region in Malaysia. The International Journal of Human Resource Management, 24(15), 30023019. https://doi.org/10.1080/09585192.2013.763841

Ketter, P. (2008). What's the big deal about employee engagement? $T+D, 62$ (2), 44-49.

Khilji, S.E., Tarique, I., \& Schuler, R.S. (2015). Incorporating the macro view in global talent management. Human Resource Management Review, 25(3), 236-248. https://doi.org/ 10.1016/j.hrmr.2015.04.001

Kianto, A., Vanhala, M., \& Heilmann, P. (2016). The impact of knowledge management on job satisfaction. Journal of Knowledge Management, 20(4), 621-636. https://doi.org/ 10.1108/JKM-10-2015-0398

Kogut, B., \& Zander, U. (1992). Knowledge of the firm, combinative capabilities, and the replication of technology. Organization Science, 3, 383-397. https://doi.org/10.1287/ orsc.3.3.383

Kundu, S.C., \& Lata, K. (2017). Effects of supportive work environment on employee retention: Mediating role of organizational engagement. International Journal of Organizational Analysis, 25(4), 703-722. https://doi.org/10.1108/IJOA-12-2016-1100

Liu, N.C., \& Liu, M.S. (2011). Human resource practices and individual knowledge-sharing behavior - an empirical study for Taiwanese R\&D professionals. The International Journal of Human Resource Management. 22(4), 981-997. https://doi.org/10.1080/ 09585192.2011 .555138

Marks, M.L. (2007). A framework for facilitating adaptation to organisational transition. Journal of Organisational Change Management, 20(5), 721-739. https://doi.org/10.1108/ 09534810710779126

Matthysen, M., \& Harris, C. (2018). The relationship between readiness to change and work engagement: A case study in an accounting firm undergoing change. SA Journal of Human Resource Management, 16, 1-11. DOI:10.4102/sajhrm.v16i0.855

McDonnell, A. (2011). Still fighting the "War for Talent"? Bridging the science versus practice gap. Journal of Business and Psychology, 26(2), 169-173. https://doi.org/10.1007/ s10869-011-9220-y 
McNulty, J. (2018). High-tech workplace tools are key to winning the war for talent. Strategic HR Review, 17(4), 176-180. https://doi.org/10.1108/SHR-05-2018-0033

Michaels, E., Handfield-Jones, H., \& Axelrod, B. (2001). The war for talent. Boston: Harvard Business School Press.

Nonaka, I. (1994). A dynamic theory of organizational knowledge creation. Organization Science, 5(1), 14-37. https://doi.org/10.1287/orsc.5.1.14

Nonaka, I., \& Takeuchi, H. (1995). The Knowledge-creating Company. New York, NY: Oxford University Press.

Oltra, V. (2005). Knowledge management effectiveness factors: the role of HRM. Journal of Knowledge Management, 9(4), 70-86. https://doi.org/10.1108/13673270510610341

Pandita, D., \& Ray, S. (2018). Talent management and employee engagement - a metaanalysis of their impact on talent retention. Industrial and Commercial Training, 50(4), 185-199. https://doi.org/10.1108/ICT-09-2017-0073

Parent, J.D., Sullivan, C.C., Hardway, C., \& Butterfield, D.A. (2012). A model and test of individual and organizational factors influencing individual adaptation to change. Organization Management Journal, 9(4), 216-235. https://doi.org/10.1080/15416518. 2012.738527

Petrou, P., Demerouti, E., \& Schaufeli, W. B. (2018). Crafting the change: The role of employee job crafting behaviors for successful organizational change. Journal of Management, 44(5), 1766-1792. https://doi.org/10.1177/0149206315624961

Saks, A. M. (2006). Antecedents and consequences of employee engagement. Journal of Managerial Psychology, 21, 600-619. https://doi.org/10.1108/02683940610690169

Scarbrough, H., Swan, J., \& Preston, J. (1999). Knowledge Management: A Literature Review. Issues in People Management. London: Institute of Personnel and Development.

Schaufeli, W.B., \& Bakker, A.B. (2004). Job Demands, Job Resources, and their Relationship with Burnout and Engagement: A Multi-Sample Study. Journal of Organizational Behavior, 25, 293-315. https://doi.org/10.1002/job.248

Shantz, A., Alfes, K., \& Latham, G.P. (2014). The Buffering Effect of Perceived Organizational Support on the Relationship Between Work Engagement and Behavioral Outcomes. Human Resource Management, 55(1), 25-38. https://doi.org/10.1002/hrm.21653

Shantz, A., Alfes, K., Truss, C., \& Soane, E. (2013). The role of employee engagement in the relationship between job design and task performance, citizenship and deviant behaviours. The International Journal of Human Resource Management, 24(13), 2608-2627. https://doi.org/10.1080/09585192.2012.744334

Shuck, B., Adelson, J. L., \& Reio, T. G. (2017). The Employee Engagement Scale: Initial Evidence for Construct Validity and Implications for Theory and Practice. Human Resource Management, 56(6), 953-977. https://doi.org/10.1002/hrm.21811

Silzer, R., \& Dowell, B. E. (Eds.). (2010). Strategy-driven talent management: A leadership imperative. San Francisco: John Wiley \& Sons.

Singh, A.K., \& Sharma, V. (2011). Knowledge management antecedents and its impact on employee satisfaction: a study on Indian telecommunication industries. The Learning Organization, 18(2), 115-130. https://doi.org/10.1108/09696471111103722 
Sonenshein, S., \& Dholakia, U. (2012). Explaining employee engagement with strategic change implementation: A meaning-making approach. Organization Science, 23(1), 1-23. https://doi.org/10.1287/orsc.1110.0651

Spender, J.C. (1996). Making knowledge the basis of a dynamic theory of the firm. Strategic Management Journal, 17(1), 45-62. https://doi.org/10.1002/smj.4250171106

Tarique, I., \& Schuler, R. (2018). A multi-level framework for understanding global talent management systems for high talent expatriates within and across subsidiaries of MNEs: Propositions for further research. Journal of Global Mobility, 6(1), 79-101. DOI:10.1108/JGM-07-2017-0026

Truss, K. (2014). The future of research in employee engagement. Robinson, D. \& Gifford, J. (Eds.), The Future of Engagement Thought Piece Collection, Institute for Employment Studies, 79-87, Engage for Success Peer-Reviewed Thought Leadership Series, Engage for Success, London.

Tummers, L., Kruyen, P. M., Vijverberg, D. M., \& Voesenek, T. J. (2015). Connecting HRM and change management: The importance of proactivity and vitality. Journal of Organizational Change Management, 28(4), 627-640. https://doi.org/10.1108/JOCM-112013-0220

Turulja, L., \& Bajgoric, N. (2018). Information technology, knowledge management and human resource management-Investigating mutual interactions towards better organizational performance. VINE Journal of Information and Knowledge Management Systems, 48(2), 255-276. https://doi.org/10.1108/VJIKMS-06-2017-0035

Van Schalkwyk, S., Du Toit, D.H., Bothma, A.S. \& Rothmann, S. (2010). Job Insecurity, Leadership Empowerment Behaviour, Employee Engagement and Intention to Leave in a Petrochemical Laboratory. SA Journal of Human Resource Management, 8(1), 234-241. DOI:10.4102/sajhrm.v8i1.234

Vuong, B., \& Sid, S. (2020). The impact of human resource management practices on employee engagement and moderating role of gender and marital status: An evidence from the Vietnamese banking industry. Management Science Letters, 10(7), 1633-1648. DOI: $10.5267 / \mathrm{j} . \mathrm{msl} .2019 .12 .003$

Wiklund, J., \& Shepherd, D. (2003). Knowledge-based resources, entrepreneurial orientation, and the performance of small and medium-sized businesses. Strategic Management Journal, 24, 1307-1314. https://doi.org/10.1002/smj.360 